\title{
CULTURAL WORKERS FROM THE PAINTBRUSH FACTORY. BETWEEN INSTITUTION-BUILDING AND URBAN DEVELOPMENT CHALLENGES
}

\author{
MARINA MIRONICĂ ${ }^{1}$
}

\begin{abstract}
The paper is an ethnography of cultural workers from the contemporary art centre from Cluj-Napoca, Romania - The Paintbrush Factory. The one-decade existence of the alternative space contributed to a range of changes in the local cultural scene and evolved from a physical space into a resource for the city's culture-led development strategy. It also became affected and reshaped by wider changes in terms of applied cultural policies. Cultural workers' perspective, their precarity and their involvement in the local art scene influenced the current commodification and entrepreneurialisation of the cultural offer. The Paintbrush Factory's expansion and contraction are vividly presented through the reflexive lenses of the cultural workers and managers, whose case-study could easily be regarded as a signal and a symbol of the deficient cultural policies mostly oriented to profit and lacking any local and long term-vision.
\end{abstract}

Keywords: cultural workers, culture-led development, independent art, gentrification, Cluj-Napoca

\section{Introduction and background ${ }^{2}$}

For a former industrial city such as Cluj-Napoca, where the majority of the population worked in factories during state communism, active urban restructuring has become a very popular measure after the global economic crisis. A cultural rebranding shapes the city's occupational structure since more artistic initiatives and cultural workers are active on the local canvas. In tight relation to this economic and spatial reality, local production of art and the

1 Independent sociologist and researcher, e-mail: marinamironica@yahoo.com.

2 I want to thank everyone with whom I discussed about the topic of this article - professors, as well as friends. Also, I'm grateful to my colleagues and co-workers from the cultural field from Cluj-Napoca, with whom I worked or shared time and thoughts about this development, while working on this paper and beyond. 
interpretations given to culture have become important resources and reference points in city development. In the last two years, I have witnessed and participated in countless academic and street-level discussions about the commodification of culture, economic growth and the necessity of densification of the inner city through the conversion of former industrial sites (Mironica, 2017) ${ }^{3}$. As a result, I came to the idea that artists who are active in participatory, social and alternative art may be able to tell something interesting about culture's role in urban development. More than this, they may have an influence, if not a word in how it's planned and brought into action. Therefore, I turned my attention to Fabrica de Pensule $^{4}$ (The Paintbrush Factory), a contemporary art centre from Cluj-Napoca, a former actual paintbrush factory, that became an important place for the local art scene in the last decade. The often-circulated term independent space in the self-description of Fabrica de Pensule (FdP) implies the intention of standing outside the state system, being independent of its constraints, values, and altered structures. ${ }^{5}$

The history of the future internationally known art space Fabrica de Pensule starts in early 2009 amid the global financial crisis, which also hit the city of Cluj-Napoca. At that point, in Cluj-Napoca, there already existed some artistic initiatives, but they were literally underground and the lack of space inside the old city walls was a pressing problem. Emptied of its original purpose, Fabrica's building was offered for lease and a few visual, conceptual and performative artists found it fitting for their purposes. Their initial need was modest - cheap workspaces - but it did spark a necessity for collective organization as more and more individuals and organizations gathered and filled the four floors of the factory.

Several art auctions later, which meant money donated by artist members and several months of conceptualization and physical work to renovate the building, Fabrica de Pensule was opened to the public in the summer of 2009. Thanks to previous artists and cultural managers' connections, foreign media discovered this conglomerate of visual and performative artists and its fame grew apace until it became impossible to ignore, both for the artistic circles and for the local administration of the city. Starting with 2015, the local municipality

3 I did research for my bachelor and master theses in the last three years (2016-2019) while being an active member of the public and sometimes co-worker in cultural projects in Cluj-Napoca.

4 The Paintbrush Factory is a contemporary art centre opened in 2009 in Cluj-Napoca, Romania and built around the building of a former paintbrush factory by a group of artists and cultural managers. More about it: http://fabricadepensule.ro/en/ (Accessed on 15.09.2019).

5 At the moment of writing and submitting this article, Fabrica de Pensule's fate is unsure and insecure. The change of the former space and the stringent need for a re-organisation and rethinking of its activity is ongoing and the end result is still unknown. Hopefully, the ten years history and the current resources will continue to live in a form or another. 


\section{CULTURAL WORKERS FROM THE PAINTBRUSH FACTORY. BETWEEN INSTITUTION-BUILDING AND URBAN DEVELOPMENT CHALLENGES}

introduced $F d P$ to a priority list of projects, which meant financial support, and consequently a recognized authority and power on the local art scene. Parallel to the increase in financial stability - due to the international Tajan auction (Paris) from 2014, internal animosities deepened too, and by 2016 the conflict between a few visual artists and the rest had reached the press. Now, three years later, it is becoming clear that 2016 meant the end of $F d P$ as the large audience knew it. Even if some projects are still ongoing and the Factory's experience continues to mark the local scene, one can talk about a different contemporary art centre than the one from 2009 to 2016, and this is not only the conflict that had marked the Fabrica's history.

\section{Methodological considerations}

Fabrica de Pensule as a long-established and recognized entity is an eloquent example of an art space which is created from scratch, articulated into a free contemporary art space for artists of all kinds and driven to an uncertain and unstable future by structural economic conditions and neoliberal public policies. The very purpose of the space and community - to become a pole of attraction for alternative arts - has turned out to be a curse when urban development knocked at their door and put pressure on their spatiality, consequently their activities. Therefore, the cultural workers and artists are exponents of the whole changing system with important consequences for the local art scene. This is why a closer look at their experiences is going to provide measures for a better understanding of the current state of affairs on the local art scene and the possible perspectives given by nowadays development projects.

This is a contribution to the knowledge about the recent development processes in Cluj-Napoca. The decision to analyse an independent contemporary art centre was motivated by my personal interest to understand the local art scene and its actors' role in it - cultural workers, institutions, structural processes. This may be a useful endeavour even for placing the Cluj-Napoca example in a regional and global context of cities competing for a more prestigious place on the high skill labour market, for a cultural consumption market and for investments in real estate and technology industries. I hope that by giving an insight into the modus operandi of creating an art centre in a rather small city I could get closer to the understanding of the role this kind of institution and its cultural workers have in the evolution of the city. Such an institution is not geographically or culturally isolated, therefore it was important to analyse it thoroughly in order to understand the factors which alter it and the kind of structures that are put at work in this kind of context. 
This research is an ethnography of a contemporary art space from ClujNapoca which I came to know both from inside and from outside in the period of three years - 2017-2019. My attendance at public theatre shows and exhibitions was doubled by sporadic work with Fabrica's members and countless official and unofficial meetings. This kind of research is inevitably subjective and it reflects a multitude of personal positions - both from the subjects of research and from me - which I recognize and assume.

I conducted sixteen interviews with visual artists, conceptual artists, gallerists, producers, art historians, anthropologists, cultural managers, generally called cultural workers. They represent people who are active now or have been so in the past in the FdP Federation, with work-spaces in or outside Fabrica de Pensule. My interviewees' social and humanistic formal education and their working practice had an important role in the explanation process due to their reflexivity and introspective attitude. In addition, my research contains informal interviews with people who interacted with Fabrica.

The perspective from which Fabrica de Pensule is going to be presented will be consistently marked by my double identity, as a sociologist and an independent cultural worker. For this reason, I will also engage in systematic critical thinking, helped by the theoretical apparatus, when I will introduce information from various interviews with past and present representatives of the Fabrica. My approach could be described as reflexive ethnography, explained by Sköldberg (2009). The auto-ethnography dimension of this research is very important because it provides a reading-key meant to contribute to the field of cultural workers and precarious workers in both sociological research and cultural scene.

Looking at the evolution of the last ten years of this contemporary art institution, a series of observations can be made and some conclusions can be drawn about the role of Fabrica on the Cluj-Napoca art scene, as well as the extent to which it influenced and marked the urban development of ClujNapoca. Through the research and writing process, it became clear that we talk about the expansion/evolution and contraction/devolution of the Fabrica. I will take a closer look at how it has evolved from an imagined community of artists to a contemporary art institution and what does this route mean in the context of a peripheral city in full urban and economic growth.

The present research is oriented toward the role of the $F d P$ on the local art scene and wider social and political context in which it evolves, but it also looks at how Fabrica's members - the cultural workers - are contributing, getting involved, transform and get transformed by their work and their practices. There are certain processes, such as gentrification or commodification which determine some more individual or particular reactions. One must also remark that the socially-engaged art which is produced or mediated by the discussed 


\section{CULTURAL WORKERS FROM THE PAINTBRUSH FACTORY. BETWEEN INSTITUTION-BUILDING AND URBAN DEVELOPMENT CHALLENGES}

cultural workers is starker oriented to all types of disenfranchised groups but it bypasses often the internal dynamics of the community. The complex relationship between the external context and the organizational structures, personal values and history is reflected in the non-functioning models brought to the city's evolution.

\section{Artists and art practices in capitalism}

Pierre Bourdieu's definition in Distinction (1984: 359) of the new petite bourgeoisie which

comes into its own in all the occupations involving presentation and representation (sales, marketing, advertising, public relations, fashion, decoration and so forth) and in all the institutions providing symbolic goods and services and in cultural production and organization

is recalled by Keith Negus (2002) in his attempt to make clear the essence of cultural intermediaries. Negus includes cultural intermediaries into this new petite bourgeoisie. Given the evolutions in the cultural field and economic reality, artists from the independent sector,

in both their working habits and routines of daily living, tend to blur a number of conventional distinctions. Most notable here is the division between high art/popular culture, and the divide between personal taste and professional judgment (or leisure and work).

The ambiguous role of cultural intermediaries is fully embraced by this notion because "it places an emphasis on those workers who come in-between creative artists and consumers (or, more generally, production and consumption)", a category more and more relevant for how we look at urbanized spaces with an ever more flexible working regime. Another very consistent dimension of this category is its representativeness for the

shift away from unidirectional or transmission models of cultural production towards an approach that conceives of workers as intermediaries continually engaged in forming a point of connection or articulation between production and consumption (Negus, 2002: 503).

Hereby, cultural workers and cultural managers are put into relevant and explanatory positions while analysing current culture-led development in urban contexts. 
Considering Martha Rosler (2016) perspective on cultural class and its mission saying that "The art world as an imagined community, in Benedict Anderson terms - as a powerful type, a post-national community held ever closer in relation to new systems of publishing and communications", I am doing a radiography of a cultural class's modus operandi in its attempt to change the state of the local art scene. Even if somehow limited and dealing with restriction due to its geographical position - being located in an Eastern European city Fabrica de Pensule is also a victim of this imaginary art world in which sources of ideas are validated on a global scale. Moreover, the imagined or fictional part comes from the need to believe in some kind of structure that would be able to bring meaning and basis for further actions. This aspect is recurrent in my interviewees' discourses, so I think it deserves to be dealt with in the frame of institution-building and developing a community.

Undoubtedly, the artistic field is known for its

lack of a well-defined career hierarchy. Compared to most industrial and some white-collar work, many art-related occupations (like painting or dancing) don't have a formal seniority system or a wage-labour situation like being hired or being fired (Sharon Zukin, 1982).

The fact drives working relations into productive, as well as destructive directions. Moreover, as Zukin (1982) astutely notes, "artists who enjoyed the direct and indirect support of the state could also be expected to show their gratitude during political campaigns." This dependency is a blessing and, at the same time, a curse for the independent sector, since their political views should either be tempered or articulated out loud, ideally regardless of them having state's financial support or not.

The profile of those cultural managers and artists who came up with the idea of associating in a communal space for the future Fabrica fits Markusen's (2006) description:

They remain a powerful source of articulated opposition to the societal status quo and a major force for innovation. In the built environment of the city, they play multiple roles in stabilizing and upgrading neighbourhoods and are sometimes caught up in gentrification.

In addition to the objective needs projected on the new space of the city, such as space for work, low rent prices, and relative independence, the initiators hoped to be part of a movement that would give them space for thought and comrades for their leisure time or public projects to be created. The expectation of civil society is that artists will be in the vanguard of artistic and even political thought. 


\section{CULTURAL WORKERS FROM THE PAINTBRUSH FACTORY. BETWEEN INSTITUTION-BUILDING AND URBAN DEVELOPMENT CHALLENGES}

Zukin (2009) finds a relation between global urbanism and the crisis of rampant capitalism, which she calls a crisis of authenticity by invoking Lefebvre and Jane Jacobs who also considered that "upscaling has brought about undesirable change in the urban imaginary, an unsettling feeling that the city is losing its soul (apud Chan, 2007). This topic is omnipresent in any context which deals with the future and directions which should be taken by the artistic initiatives and alternative spaces. The financial crisis and/or lower support from the state's institutions are making artistic practice more restrained and precarious, but as Zukin (2009) is pointing out, all this "should not prevent us from transforming the aesthetics of global urbanism into support for a just and diverse city." She writes about the necessity to prevent up-scaling and displacement through the politicization of "the meaning of authenticity to include the right to put down roots, a moral right to live and work in a space, not just to consume it" (2009).

There is also the slot occupied by participatory art as described by Claire Bishop in her Artificial Hells: participatory art and the politics of spectatorship (2012). Bishop gives a short recount of participatory art which consists of an artist "conceived as a collaborator and producer of situations", the work of art which is now unlimited by time and space - and the audience, "now repositioned as a co-producer or participant". Walter Benjamin (2015: 14) reflects on the importance of an art form and remarked a relatable aspect:

The greater the decrease in the social significance of an art form, the sharper the distinction between criticism and enjoyment by the public. The conventional is uncritically enjoyed, and the truly new is criticized with aversion.

Even if he said it with regard to the technologically reproduced art, it stands also for the contemporary and alternative art of our time.

\section{Cultural workers and the cultural precariat}

Alexandra Oanca makes a splendid retrospective of the state of affairs in the cultural sphere in Spain in her Ph.D. thesis Bidding wars (in the Spanish competition for European Cultural Capital). Oancă (2017: 191) reminds us that the term cultural operator or cultural entrepreneur comes from cultural policies at the level of the European Union. As she underlines, the officials

do not prioritize the production dimension of culture but they privilege culture for the economic impacts of the arts, and the cultural sector (tourism and spectacle), individualized consumption, and EU soft diplomatic power promotion. 
The etymology of cultural entrepreneurs in the era of commercial art production is described in the following way: "Through the combination of these two terms, culture and operators, culture is seen as an instrument, as a coherent, closed element; almost like an object" (Oancă, 2017: 191). In this framework, culture is easy to be instrumentalized for economic and urban growth purposes.

Artists and cultural managers are part of a wider city-ranged discourse about culture and how should it be involved in the development, sometimes without being aware of it. Kothari via Oancă (2017: 196) brings up the example of relations of power in the situation of someone who is invited to participate in a project, to contribute with ideas and to have the possibility to shape a strategy. Cooke and Kothari (2001) define as 'political co-option' what happens when someone's ideas get incorporated in a project out of the initial context when some input is perverted by the general frame. Adverse incorporation (G. Wood, 1999; Kothari, 2005) is regarded as a negative experience of participation. Since the artists and public activists are anyway very fragile because, in most cases, political managers or project managers don't mention them in the final version of work, it's even more disagreeable when an idea is incorporated and conducts to totally different results.

In addition, with the institutionalization of culture and instrumentalization of artistic production "local artists are a pool of free or underpaid (im)material labour both for ideas and for implementing the imaginaries of the city, particularly for its festivalization and museification" (Oancă, 2017: 196). The intensification of cultural activity, whether it resulted out of competition with other near cities, tourism or local consumerism drives to "the rise of the creative precariat which is one of the contradictions intrinsic to inter-urban competition and to the pressure to instrumentalize everything (Arvidsson, Malossi, and Naro, 2010; Holt and Lapenta, 2010; de Peuter 2014; Bain and McLean 2012; Mclean 2014 apud Oancă, 2017: 199).

Nowadays the situation of artists might seem as old as the world, but it's not: the precarity of artists is directly influenced by the neoliberal capitalism we live in. The idea that an artist should be flexible and always ready for selfexploitation in the name of art with the price of her present and future social security is a new shade on the labour market (Oancă, 2017: 199). Moreover, this unavoidability of precarity is used by the state and the local administration to produce more artistic resources for economic urban development.

The right to the city is denied to those who are creating it through their ideas and their community participation. "The selling culture and selling the city as a commodity" (Oancă, 2017: 199) constrain cultural workers to 


\section{CULTURAL WORKERS FROM THE PAINTBRUSH FACTORY. BETWEEN INSTITUTION-BUILDING AND URBAN DEVELOPMENT CHALLENGES}

widespread alienation and resentment because they experience first-hand the appropriation and exploitation of their creativity for the economic benefit of others, in much the same way that whole population can resent having their histories and cultures exploited through commodification (Harvey, 2013).

In this context, commodification refers to the usage of some previously non-profit resources in order to develop the economy and to reflect present entrepreneurial class interest. It is implemented with the contribution of urban strategies proposed and supported by the middle class and its representatives in municipal functions - and art is one of the main commodified instances inside culture-led development.

On the other side, this very precarity could enable artists to stage critical encounters in relation to the main discourse about cultural production. Their involvement in a culture already monopolized by competitiveness and consumerism could create "potentially subversive subjectivities and a potentially subversive discourse" (Oancă, 2017: 200). Even though this is an option, the possibility of reproducing the status quo should be considered as a contraargument for this approach. The inevitability of alienation circle - as in the case of Donostia - San Sebastián, a project discussed by Oancă (2017: 218) - makes cultural actors wish at least to contaminate wider culture-led development strategies. This could be seen as the kind of cynicism Illouz invokes in saying that it is "a particular structure of feeling which emerges ... in late capitalist societies (....) cynicism is the tone one is likely to use when one sees through and yet feels compelled to the same thing over and over again" (Illouz, 2007: 89 apud Oancă, 2017).

\section{Making a commodity out of the culture}

Walter Benjamin (1970) writes about the aura of the art object and how it is transformed into contemporary culture due to technological reproduction and changing cultural practices. The trading market of artistic products is facilitating exchanges while this creates the opportunity for translating immaterial capital into economic capital. As consumption of niche-, high-, mass-art extended and made way to more diverse social groups of the middle class interested also in commercialization and profit-making, it became harder to trace the line between engaged in the market and engaged in social change art (Bayly, 2004 apud O'Connor, 2010: 16). However,

this creative field allowed the emergence of a restricted economy of artistic products that explicitly rejected market success yet gained high prestige (cultural capital)

- which, in turn, could translate into economic success (O'Connor, 2010,17). 
In the present capitalist market framing, it is difficult to limit yourself from engaging with the mainstream value system or to withdraw from the need to have material and financial demands, which brings even the most independent and critical artist to a state of confusion.

\section{Fabrica's very beginnings}

The history of Fabrica de Pensule - whether at its end or still in the process of articulation - is strongly related to the broader context of what is Cluj-Napoca and how its cultural economy worked after 1990. Fabrica's evolution took place in the biggest city of Transylvania, a city with a multi-ethnic background, but also with a history of cultural stagnation until the 2000s. The lack of cultural events on offer and the scarcity of affordable spaces at the end of 2000 made this collaborative project desirable and possible. From there on, a melange of factors contributed to its success and also to its impact on the city. Hereinafter, I'm going to discuss a few of them, namely the transformation of the community's relationships with local municipal and non-governmental institutions (I) and the cultural worker's status as it was shaped by the European cultural policies (II).

The initial building of the community and later of the institution was, to a large extent, grounded in personal imaginaries about what a place such as Fabrica de Pensule could be(come). The motivations and values became transparent for some of the members from the point when they decided how Fabrica was going to be organized and managed:

[Communitarianism] has always been a matter assumed by a few people who happened to be at the helm and to direct the speech, give the tone, the opinion-makers in the Fabrica, but it was never a major trend. (K1, m, cultural manager, Cluj-Napoca, 2019).

Moreover, the projection of their personal role and of their art on the common picture of what Fabrica was going to become is easy to see from the current standpoint when its members recollect their motivations:

You contribute to an institution whose agenda looks directly at you, with people of the same generation and with common views, I think this seemed to be an asset and it really was (K2, m, visual artist, Cluj-Napoca, 2019).

My interviewees, though, claim that at the beginning no one really knew or imagined what they were going to build and what role it would have in their lives, as artists and managers. Neither was it clear how it was going to change 


\section{CULTURAL WORKERS FROM THE PAINTBRUSH FACTORY. BETWEEN INSTITUTION-BUILDING AND URBAN DEVELOPMENT CHALLENGES}

the art scene and the future brand of the city of Cluj-Napoca. Maybe only the international media appearances ${ }^{6}$ were predicting the future recognition and the increase of image and financial capital.

\section{Fabrica's role - a view from inside}

Art experiments have been held inside Fabrica's walls, and a lot of cultural and organizational practices (collaborative working-spaces, horizontal collaborations, and common activities planning) have been imported from abroad and put to work in the institutionalization process. New contemporary dance and theatre shows have been brought to the Romanian and local art world through a variety of partnerships and Temps d'Image Festival. A cultural manager and producer responded to my question about Fabrica's impact as follows:

If we want to identify the role of the Fabrica, it was to break down [the monopol] of some institutions, but it wasn't an assumed role. The people who started with us or succeeded within our walls also managed to break down some [other] institutions, which later became more open to this type of art manifestation (K3, w, producer, Cluj-Napoca, 2019).

The reality of the local art scene was indeed poorer in artistic practices while knowledge about non-governmental organisation just started to be practiced and embraced. Fabrica's institutionalisation served as an example of how to practice, organise, exhibit, coordinate artistic and cultural projects or not.

The progress made by visual arts during the Fabrica's activity is difficult to be measured. However, the appetite for alternative exhibition spaces has increased over the past ten years. Also, the galleries that have existed over time in the Fabrica are proof that there are possibilities for affirmation outside of state museums. An artist told me that he thinks

there are good artists who have walked around here, and I think this place has managed to gather the energy of the city, it had its role. Hence some artists have matured at the Fabrica. And some practices. And that's what you could see in exhibitions every year (K4, m, graphic artist, FdP member, Cluj-Napoca, 2019).

6 Ney York Times: https://tmagazine.blogs.nytimes.com/2013/11/12/art-matters-a-medievalromanian-city-with-major-art-talent/?smid=tw-share\&_r=4 [From 12.11.2013, accessed in May, 2019], and Huffington Post: https://www.huffpost.com/entry/art-cities-of-the-future_n_3949998 ?guccounter=1 [From Huffpost 19/09/2013, accessed in May, 2019]. 
The international recognition that came with the discovery of the Fabrica in the West - articles in some of the most famous magazines as the New York Times and Huff Post - helped the artists gain higher credits from outside and gave them more confidence in their own work and their value as artists and cultural workers.

\section{Relations with other actors and stakeholders}

In the aftermath of the 2016 conflict between the two groups of Fabrica's members, the completeness and integrity of the institution have suffered. A newly founded contemporary art centre - Centrul de Interes [Interest Centre] - the result of the break-away group which had a part in the conflict became a competitor for Fabrica, both on the art scene/market and for the municipal financial funds. Although they have different approaches toward art and also their social (dis)engagement on the local scene, from the outside the purpose of the Centrul de Interes is understood as being similar to Fabrica's purpose. Therefore, Fabrica's financial support from the municipality has diminished, even though the price for the rent went higher. The political profile of Fabrica has also contributed to the unequal support from the public sector as well as from the art world. A subjective explanation to the diminishing level of praise is given by one of the former executives, who spots the political animosity towards the assumed civic role of the Fabrica:

If we were nice, we didn't say anything, we went to [private events of] public functionaries, had not been going to protests, Fabrica would have survived [perfectly] (K7, m, cultural manager, FdP member, Cluj-Napoca, 2019).

At the time when the Canadian company Roșia Montană Gold Corporation (RMGC) was in the process of getting from the Romanian state the right to exploit gold at the mine in Roșia Montană (located at $127 \mathrm{~km}$ from Cluj-Napoca) ${ }^{7}$, huge image washing campaigns were on roll. One of the events funded was also TIFF (Transylvania International Film Festival) ${ }^{8}$. Fabrica, while in the first years of its operation, launched a wider protest action against TIFF by rejecting the partnership between the two entities. One of the Fabrica members has given me this example of an internally widely-accepted civic activism:

7 More on Roșia Montană protests: https://www.theguardian.com/environment/2013/sep/04/ protest-rosia-montana-gold-mine-protest, (Accessed on 16.09.2019).

8 Local international film festival and one of the main events from Cluj-Napoca: https://tiff.ro/, (Accessed on 16.09.2019). 


\section{CULTURAL WORKERS FROM THE PAINTBRUSH FACTORY. BETWEEN INSTITUTION-BUILDING AND URBAN DEVELOPMENT CHALLENGES}

You cannot say "I paint and I have nothing with RMGC", in the context in which the whole society has something to say and you are sitting in your workshop. We all agreed there (K3, w, cultural manager, FdP member, ClujNapoca, 2019),

remembering also the direct and serious consequences that their action had. The cultural community in Cluj-Napoca joined the protest, and the TIFF rejected RMGC funding, but the relationship with Fabrica suffered. Such a case reflects perfectly the power an organized group has when it decides to act, but also the vulnerability it undergoes, given the possible conflicts that arise and which may derail the rest of the artistic activities.

\section{'Art for art' and art for commodification}

Art and culture are immaterial resources easily available as subjects of construction, commodification, and emancipation. It is on those who produce and diffuse them if they will serve for profit-making only, or for emancipation and developing social awareness. The fact that "artists serve as the conscience of the society: the most likely source of merciless critique and support for unpopular issues such as peace, the environment, tolerance, and freedom of expression" (Markusen, 2006) is an affirmation I found telling for the ClujNapoca intellectual and artistic circles' expectations from FdP. In fact, this description is true only partially because the initial Fabrica's association of forces - both artists and organizations - were not philosophically discussed, so the political views differed on a quite wide spectrum. Hence, expectations have suffered disillusionment, while clashes of beliefs put more and more pressure on the horizontal organization.

Talking with the artists and cultural managers involved in the making of the Fabrica de Pensule program I could distinguish between those who, from the very beginning, wanted to produce a kind of participatory art, and those who were interested in relational aesthetics, as Nicolas Bourriaud (apud Bishop, 2012) sees it. Those who remained in the building and continued their work, after the conflict, are akin to the participatory art described by Bishop, as it is observed from their practice. The difference is also present in the Fabrica's members discourse:

At the performative art you always have a public, you manage the public, community feelings; you have to give in general, it's a collective redistribution, and there [in visual art] is accumulation in private $(\mathrm{K} 1, \mathrm{~m}$, conceptual artist, FdP member, Cluj-Napoca, 2019). 
The awareness among $F d P$ regarding distinctions in personal values was unequal, thus reactions to the difficulties and the interests that occurred over time were different. The story told to me by a cultural manager and current member about day-to-day divergences -

and then you have all sorts of conflicts on the corridor, "but it's the [loud] audience" at the show, yeah, but that's it, or "you left me beer caps on the hall when the art collector comes to me (K9, m, artist, FdP member, ClujNapoca, 2019) -

reflects both the logistical and the philosophical discrepancy between the members. An example of the conflictual political views on the role of art shared by different members of the Fabrica is the case about the hosted activity of PAC (Autonomous Market Cluj-Napoca) ${ }^{9}$, a local group who militates for inclusion and gives help - food, hygiene, and first-use products - to poor and disadvantaged people from Cluj-Napoca. After a few editions organized by $P A C$ which took place in the Fabrica, they stopped hosting PAC and, as someone told me,

there were voices who said that we should not join leftist directions, or whatever. Not all members agreed with the social component. There is no consensus about "we help the poor and we all accept them". There are voices saying, "I do not want to deal with it, and it does not represent me." (K3, w, cultural manager, FdP member, Cluj-Napoca, 2019).

The ambiguity in Fabrica's public discourse was always present: the outside visitors chose what fits them and their views while ignoring the rest. However, for the insiders, it was harder to work and to build something together - an institution which was becoming more and more important - and not agreeing on how art should be financed; if it should convert public money into private profit, or whether it should take part into political and civic actions or not, and so on.

Szilárd Miklós, an active member of a different alternative art initiative from Cluj-Napoca, said in an interview for Gazeta de Artă Politică ${ }^{10}$ :

While ephemeral practices and forms of self-organization that resist commodification abound even today at the edge of the great institutions of art, all forms of resistance are embedded in the hypermarket of the ongoing revolution of Western modernism. This dual state has been internalized by contemporary art institutions in our geographical area.

9 Organized by the local anarchist collective: https://acasa.blackblogs.org/, (Accessed on 16.09.2019).

$10 \mathrm{http}$ ///artapolitica.ro/2018/06/10/dosar-scoala-populara-de-arta-contemporana/ (Accessed on 15.09.2019). 


\section{CULTURAL WORKERS FROM THE PAINTBRUSH FACTORY. BETWEEN INSTITUTION-BUILDING AND URBAN DEVELOPMENT CHALLENGES}

This thought is shared by other artists from the local scene. The awareness that their artistic product will get commodified and used for profit raising is often very pregnant among visual artists targeted here:

I prefer clean, non-capitalist bullshit areas, but I think you cannot escape. And non-profit foundations and galleries that make left-wing projects, in general, are funded by large banks. It's complicated to be really an outsider (sculptor, m, FdP member, Cluj-Napoca, 2019).

Yet the gallerists are usually more pragmatic and permissive with the interference of the market in their professional artistic life, a perspective that often clashed with other more radical visions.

The art market is pressuring on artists, and higher education institutions are embracing the commercial dimension of art, hence, Fabrica could not escape this pattern. ${ }^{11}$ Consequently, there are artists and managers who are keen on commercial success and there are those who oppose it. They cohabitated in the same building and tried to build a common contemporary art centre which lasted for a while. Nevertheless, the discussion on whether art should oppose the market, or should undermine it, or should embrace and work within it, is still open. The lived experience proved, though, that while discussions were being held, the financial capital-driven reality became too harsh a challenge even for an institution of art that envisioned itself as "alternative".

\section{The perverted cultural workers' critical discourse}

The representatives of $F d P$ are subject to the description given by Alexandra Oancă (2017: 191) to the European cultural policies and their profitoriented purpose. The community articulation and establishing came with great expectations both from the inside and from the outside of the group. Due to global trends in culture economy and the entrepreneurial approach to it, culture is regarded as just another service operated by artists, preferably according to the free-market rules, thus expected to bring profit and symbolic capital for other

\footnotetext{
11 The pressure of the art market is more of a problem for visual arts, since there are auctions, and a selling market which influences the value and the dynamics across the field. In the context of the $F d P$, visual arts dealt and struggled more with financialization. The performative arts do not have such financial complications and they fight for their legitimacy and survival without the help of the market, relaying only on the audience and public funds, as a rule. Therefore, it should be considered that the commercial dimension is more often related to the visual arts. Nevertheless, the massification of contemporary theatre and the development of the local art scene influenced the founding of the performative arts from $F d P$ too.
} 
economy branches. The local administration development strategies and the rule of the free market reshaped the underground, non-profit activity of the local artists and the local organisations into a branch working for city-image rebranding. The object of this process was not just $F d P$, but the whole local cultural sector which emerged and/or flourished in Cluj-Napoca from the moment of the candidacy for the title of European Capital of Culture, a process that lasted from 2011 to 2016. Moreover, as FdP became an important actor on the local art scene it started to be seen more as part of an industry, not of a scene, which in the public imagination has been translated into a professionalized and highly organized, desirable place for any emerging or already established artist or cultural worker. Moreover, the constant association with the creative industries, even if denied by $F d P$ members, stuck to the independent cultural sector, a label which came with different expectations from the authorities and parts of the public and with struggles for identity if looked from inside of the group.

In this logic of considering the culture and cultural operators as assets and sources of a good image for the city, $F d P$ has become a reservoir of cultural managers and artists eager to contribute to the development of Cluj-Napoca and to its bid to the title of European Cultural Capital for the year 2020. The developments associated with this bid worked, in fact, as an infusion of European cultural policy to the local scene. Using terms like cultural operator was met without any circumspection and quickly became unquestionable even for some of the cultural workers who are cultural managers and culturepreneurs now.

Nonetheless, there were attempts to analyse Fabrica's climate from a critical perspective in an in-house project called Art hotspots ${ }^{12}$. On this occasion, architects, sociologists, and art theorists have been invited to discuss in a theoretical framework what is the Fabrica and how its various aspects work. Norbert Petrovici (sociologist) wrote about the internal organization and division of labour in 2015-2016, Iulia Hurducaş (architect) analysed the process of building and articulation of the Fabrica's space and the meanings of that formula, and Alina Serban (art theoretician) contextualized the aesthetic effort and artistic content that the Fabrica had at the time. Such critical approaches, even if occasionally implemented by $F d P$ members, did not have a full impact on the community, for many reasons. Among them there is the acute lack of time to analyse and reflect, as cultural workers are in constant search for funds for their artistic projects, as well as the reluctance to give up already available and incorporated practices and beliefs about art and politics.

12 https://fabricadepensule.ro/hotspotart/media/publicatii/, (Accessed on 15.05.2019). 


\section{CULTURAL WORKERS FROM THE PAINTBRUSH FACTORY. BETWEEN INSTITUTION-BUILDING AND URBAN DEVELOPMENT CHALLENGES}

\section{Fabrica in the times of city's gentrification}

Even though it may seem too dramatic, I will cite an interviewee who says:

Cluj-Napoca is in the post-FdP epoch. Because the $F d P$ was a very cool utopia, people went on from a necessity that was real, and not one that was generated by marketing or the idea of art-town Cluj-Napoca; there was no such idea, nor in our heads, there was no brand, there were no collectors, and there was no IT city. We were just doing it (K5, m, gallerist, Cluj-Napoca, 2019).

This description looks back with nostalgia to the time when everything was simply spun out of enthusiasm, without any clear foreseeable cultural or financial capital. This idealised reality is also part of Fabrica's history and its imperative to analyse it toward a better understanding of alternative projects and their influence of the city development. There is already an awareness of the city standpoint among cultural workers and artists:

The pressure of financing and real estate development will be seen in the various artistic practices - performance, theatrical, visual arts; we will see a decrease in the intensity of the projects, their level (K6, m, visual artist, FdP member, Cluj-Napoca, 2019).

Considering the current phase of the local cultural and artistic production, characterized by the precarity of the alternative art and a fabulous momentum of fast-cultural events, festivals and the rampant entrepreneurialisation of public culture and space, there may be something to be weighed by the next generation.

The question of whether the Mărăşti ${ }^{13}$ neighbourhood's gentrification has been made by Fabrica has no answer in sight. Indeed,

the bus on Henri Barbusse Street [where the Fabrica building is located] appeared not due to $F d P$, but because of the IT buildings that are there and the growing area. (K3, w, producer, FdP member, Cluj-Napoca, 2019).

But these two entities - the Fabrica and the IT offices are part of the same urban development strategy and thinking direction, which was proposed and made possible by local officials and enthusiastic cultural workers, at the same time. Strategies that contain the commodification of Fabrica's initiative

\footnotetext{
13 One of the big neighbourhoods from Cluj-Napoca, built in the state-communism time for the workers, and defined by a high concentration of buildings, meant to serve the near-by factories' workers. Fabrica is located at the outskirts of this neighbourhood.
} 
for image and capital advantages at the city level, whether the idea of building on culture came first or the possibility to develop cultural initiatives were made possible by urban development strategies. The commodification is implemented with the contribution of urban strategies developed and supported by the middle-class citizens in the creative branch and its representatives in municipal functions. This means that there is a class- compromise around the priorities and the interests of people living at this time in Cluj-Napoca, even though there are small islands of resistance.

Cluj-Napoca makes, therefore, an example of a late-stage gentrified city, with many shortcuts and with wider effects at the city level. The stakes here are rather for the business sector. The city has become a place for investors' tourism looking for economies still unmonopolized and open for their contribution to urban restructuring, real estate development and jobs paid with the minimum wage (a few times smaller than in their home countries). The global competitiveness of Cluj-Napoca resides in its not fully commodified culture and not yet converted industrial platforms. The accession of the city in the regional and global competition on the market of cultural products and the high-skilled labour market raises some questions concerning local reality when it comes to cultural necessities or authentic representation.

The questions arising here are (1) which segment of the population benefits from the recently created collective symbolic capital, (2) which segment is highlighted and (3) which aspects are not considered suitable for inclusion in the city image. The answers are (1) culture entrepreneurs, business and real estate owners, (2) the creative young middle class open to multiculturalism, (3) unskilled workers, poor and disadvantaged groups. This is problematic for the inclusive development of the city, but it also offers space for hope, as Harvey calls it (2008: 112 ), to mobilize this creative class to build a new kind of globalization and anticommodification policy, which is basically possible for the case of Cluj-Napoca, taking into account the examples of protests, intellectual groups, and existing public actions. The power of cultural workers in this context is disputable, though, due to their advantages - being aware of the changes while contributing to them - and also due to their disadvantages - being in a constant state of precarity which limits not only the space for political manoeuvre but also for local and individual reflexivity.

Looking retrospectively at the last ten years of Fabrica de Pensule and at the whole art scene of Cluj-Napoca, there are voices of active cultural workers, among which some Fabrica's members, who say that the quality and the authenticity in the number of events have decreased. Zukin (2009) advances the idea of of a "crisis of authenticity", which she relates to global urbanism and the crisis of rampant capitalism. Alternatively, the richer offer contributes to 


\section{CULTURAL WORKERS FROM THE PAINTBRUSH FACTORY. BETWEEN INSTITUTION-BUILDING AND URBAN DEVELOPMENT CHALLENGES}

competition among cultural producers, a positive thing according to some more liberal opinions. Meanwhile, the global competition the city has joined comes with more initiatives and cultural events oriented toward a global public - such as music festivals (Untold, Electric Castle). They are unrelated to local history and identity; therefore they alienate locals. The applied urban development strategies of Cluj bring "undesirable change in the urban imaginary", while the citizens experience an impression, as described by Jane Jacobs, that the city is losing its soul (Chan, 2007).

\section{Conclusions}

Fabrica de Pensule and by extension its cultural workers have become the subject of my research because I had the chance to work among those people, to go to the events they organize and to experience partially their recent history. Hence, I decided to look into this contemporary art centre's working dynamics, values and principles articulation process and, most importantly, to see how the wider development strategies of the city interfere with cultural policies and cultural workers' experience within this organization. Fabrica de Pensule proved to be an excellent case study for digging deeper into the recent cultural and economic history of the city of Cluj-Napoca. Fabrica's ten-years evolution unfolds perfectly parallel to the development of Cluj-Napoca from the global financial crisis up until now, when we live at the peak of the current capitalist cycle.

The imagined community which Fabrica de Pensule was at the beginning, before receiving public acclaim, has evolved into an imagined institution that was supposed to fulfil different expectations and projections of its members. It has become also a mirage for people interested in foreign art and for experts in the area. Later on, the whole institution and the possibilities given by it made it grow and contribute to the broader art scene, probably unready for such a project, but just in time to become commodified and used as an opening for investments in what has become a diverse and creative city. Fabrica de Pensule and as a following the city of Cluj-Napoca are social products in Henri Lefebvre' terms because they have become not only material spaces but also spaces represented by specific public discourses - of success, novelty and profitability - and also representation spaces, where phenomena such as conflicts, commodification, entrepreneurship take place.

I inquired whether its members - artists and cultural workers - play the role of gentrifiers or of those who are gentrified. The social and political reality proves that they are part of a structure, made of cultural workers and cultural 
entrepreneurs, municipal functionaries and resisting groups, and the cultural representatives are not always aware and able to resist when their ideas are perverted or commodified. Even though Fabrica's discourse and practices were not formulated as part of an urban development project, it ended generating commercialization of the cultural scene, contributing to the gentrification of the neighbourhoods and of the whole city. Particularly the city's social structure, therefore consumption patterns, have been updated and connected to the newly extended middle-class' financial resources and leisure demands.

Fabrica and the city's art scene evolved toward a context in which the cultural offer "provides a cultural basis for rituals that makes class solidarity obscure and hard-to-see" (Gartman, 1991). This is precisely the role of culture and artistic production in Cluj-Napoca nowadays due to the rather touristic and mass culture that is promoted, in the face of content that draws lines of reference for resistance and awareness toward the stage of consumerism and entrepreneurship in which society is located. The empirical analysis conducted in this paper is an attempt to answer the question about the cultural workers involved in creating the cultural context of the city while being part of a wider culture-led development urban strategy. I try to make sense of narratives, subjectivities, institutional and personal struggles, global processes as gentrification and art commodification and their impact on the local level.

My immersion in the subjectivities of those involved in the foundation and development of the largest independent art centre in Romania up till now has proved to be a forming experience for me, and I hope also for those who will decide to read this text. My visits and collaboration with Fabrica de Pensule made me curious and very sensitive about its past and particularly about its possible future(s). The subjective allure this research acquired is both a fulfilment and a warning sign for me. My ambiguous role as a researcher and cultural worker simultaneously provided me with a better ability to understand the struggles of those producing and diffusing cultural products and the limits such a precarious position has.

The last three years have produced a lot of anxiety but also wisdom about the role of the culture in urban development, about the strengths and weaknesses of cultural workers in a city that is going more unaffordable by the day. There were moments when in the same phrase someone told me with awe "We made the Fabrica look very good and have thousands of people at vernissage and events, it was an enormous 'human swarm' "and then continued by saying

We should not fall into the feathers, eventually, any empire can collapse, you know, and it is interesting how praised and renowned you have been in the country and around the world (K8, w, anthropologist, FdP member, ClujNapoca, 2019). 


\section{CULTURAL WORKERS FROM THE PAINTBRUSH FACTORY. \\ BETWEEN INSTITUTION-BUILDING AND URBAN DEVELOPMENT CHALLENGES}

This sort of attitude is what gives me a straw when thinking about what can be done by artists, cultural workers and general citizens living in an increasingly entrepreneurial city. Assumed reflexivity is one of the main concept which comes to my mind when thinking about the relationship Fabrica's members have with that space and place. The theorization and analyses made by them during our talks have been the best thing could happen to me as a young cultural worker and researcher. Our shared reflections on their experience with Fabrica's history is a consistent incentive for my conceptualization of ethnographic data.

The discussion of whether there is anything to be considered from Fabrica de Pensule's present and future experience - as an independent cultural centre in a city that made a mantra from culture-led development - should be defined by the high influence of finance and politics on the cultural sector. The unequal impact of financial structures and of the investment rush on various cultural dimensions - commercial and social art, independent and institutional art - brings considerable changes, both to the art scene and to the economy. The structural status-quo overpowers easily what artistic initiatives can do as resistance practice to the mainstream cultural products. The existing critical discourse needs to be recognised and praised because the role of art and cultural workers in the capitalist mode of production is to provide space for expression and reflexivity. Therefore, only a more fundamental reconsideration of prioritized political values and public policies could bring a change in the way urban culture and urban space are administrated, in order to provide a representative space for the marginal categories too, and to reclaim our communal right to the city.

\section{REFERENCES}

Benjamin, Walter (1970). The author as producer. New Left Review, 1(62), 83-96. Benjamin, Walter (1969). Illuminations. Schocken Books.

Benjamin, Walter (2015). Opera de artă în epoca reproductibilității sale tehnice [The Work of Art in the Age of Mechanical Reproduction]. Tact.

Bishop, Claire (2012). Artificial Hells: participatory art and the politics of spectatorship. Verso.

Bourdieu, Pierre (1984). Distinction. A Social Critique of the Judgment of Taste. London: Routledge.

Castree, Noel; Gregory, Derek (2008). (Eds.). David Harvey. A Critical Reader. Blackwell.

Chan, Sewell (2007). Has New York lost its soul? City Room. The New York Times, 4 October. URL http://cityroom.blogs.nytimes.com/2007/10/04/has-new-yorklost-its-soul (Accessed on 20th May 2019). 
Illouz, Eva (2007). Cold Intimacies: The Making of Emotional Capitalism. Malden: Polity Press.

Gartman, David (1991). Culture as Class Symbolization or Mass Reification? A Critique of Bourdieu's Distinction' AJS Volume 97, Number 2 (September 1991): 421-47.

Harvey, David (2013). Rebel Cities. From the Right to the City to the Urban Revolution. Verso.

Lefebvre, Henri (2007). The production of space. Blackwell.

Markusen, Ann (2006). Urban Development and the Politics of a Creative Class: Evidence from a Study of Artists in Environment and Planning A: Economy and Space 38, no. 10 (October 2006): 1921-40.

Mironica, Marina (2017). The urban restructuring of Flacăra and Napochim factories. $A$ playground for real estate investments. Unpublished Bachelor Thesis.

Negus, Keith. (2002) The work of cultural intermediaries and the enduring distance between production and consumption. Cultural studies, 16(4): 501-515.

Oancă, Alexandra (2017). Bidding wars: Enactments of expertise and emotional labour in the Spanish competition for the European capital of culture 2016. Ph.D. Thesis, unpublished.

O'Connor, Justin (2010). The cultural and creative industries: a literature review [2nd ed.]. Newcastle: Creativity, Culture and Education.

URL https://www.creativitycultureeducation.org/publication/the-cultural-andcreative-industries-a-literature-review/

Sköldberg, K (2009). Reflexive methodology: new vistas for qualitative research. Sage.

Rosler, Martha (2016). Clasa culturală [Culture class]. Idea Design\&Print.

Zukin, Sharon (1982). Loft living as 'historic compromise' in the urban core: the New York experience. International Journal of Urban and Regional Research, 6(2): 256267.

Zukin, Sharon (2009). Changing Landscapes of Power: Opulence and the Urge for Authenticity International Journal of Urban and Regional Research. Volume 33 (2): 543-53. 